\title{
SOCIAL CAPITAL: LIMITATIONS OF THE CONCEPT AND PARTICIPATION IN PUBLIC LIFE IN POLAND
}

\author{
Kamil Aksiuto \\ Maria Curie-Skłodowska University in Lublin
}

\begin{abstract}
The article examines some of the most common and crucial difficulties involved in the use of the concept of "social capital" for research purposes. Some of the limitations of the concept are subsequently exemplified in the ways in which it has been employed to explain the unwillingness of a large part of the Polish society to participate in the public life. Social scientists have often accounted for this by emphasizing the low level of social capital in Poland, i.e. absence of certain skills necessary for active engagement in public life and/or lack of trust (trust in public institutions as well as towards other people in general). The article argues that such explanations are either obscuring important factors which contributed to this state of affairs or might gloss over the resources of social capital which are present in the Polish society.
\end{abstract}

Key words: Bourdieu Pierre, Coleman James Samuel, Fukuyama Francis, Putnam Robert David, Poland, social capital, trust.

\section{INTRODUCTION}

The concept of social capital has made quite an astonishing career over the period of, roughly, the last three decades in many fields of scientific enquiry. It has been used extensively in economics, sociology, political science, psychology and in other disciplines to account for an ever-growing list of phenomena. Furthermore, the concept of social capital has also found applications outside the academic circles, in the policy-making and media.

The purpose of this paper is twofold. Firstly, I will argue that a critical appraisal of the concept of social capital itself reveals a number of serious limitations in its usefulness and explanatory power. ${ }^{1}$ While this does not mean that those difficulties cannot be transcended by further refinement, I do want to stress that the general trajectory of the concept's development led to the increase in its popularity at the expense of its clarity and ability to provide interesting insights. Secondly, I will use the example of how the concept of social capital has been employed to account for the willingness (or to be more precise, lack of it) of the Polish people to participate in public life after the collapse of communism. This approach should help to highlight some of the difficulties with the concept invoked already in the first part of the paper.

1 I will not address in the paper at hand another line of criticism, which boils down to the conclusion that social capital is just a fashionable contemporary word for processes and issues which had been described and analysed by the classical sociology from Marx, through Durkheim and Weber, to Simmel. 


\section{THE CHALLENGES OF THE CONCEPT}

Let us begin by stressing the obvious, there is no single theory of social capital. In fact, we encounter a number of theoretical approaches which employ this concept. It is almost universally recognized that among the most influential theorists of social capital (and sometimes also popularizers of the concept) 4 figures stand above others: Pierre Bourdieu, James S. Coleman, Robert D. Putnam and Francis Fukuyama. The problem is not however that there is no single, unified definition at our disposal. That after all is the case with a whole range of concepts which are crucial for social sciences. For instance, there is no universally accepted definition of democracy and various theories of democracy deploy this concept in different ways. So, the difficulties with social capital do not simply originate from this theoretical multiplicity. It is rather that theories of the 4 abovementioned classics of the literature on social capital are not only different, but also largely incommensurable. While they all employ the same concept, the role that it fulfills in their individual accounts can only be understood when put in context of the larger theoretical wholes, ${ }^{2}$ or even historically established schools of thought, which differ in their explicit and implicit assumptions. Therefore, it is also unsurprising that the abovementioned authors apply the concept for widely divergent purposes. For instance, Pierre Bourdieu's account of social capital is embedded in his poststructuralist, marxist analysis of the social stratification and the various ways in which the social hierarchy is reproduced over generations. There is very little that this has in common with Robert Putnam's approach who originally used the concept of social capital to explain the differences in the functioning of democratic self-government in Italy ${ }^{3}$ and later invoked it in the context of the anxieties over the supposedly diminishing "civic virtue" of the citizens in the USA ${ }^{4}$ and other Western democracies. What follows from this is that one cannot combine elements of different theories of social capital, as if they were pieces of the same puzzle, without running the risk of serious incoherence.

Secondly, different definitions of social capital can be placed somewhere on the scale between two extremes, neither of which is particularly attractive, although for very different reasons. On the one end of the spectrum the concept can hardly meet the explanatory burden that is being put onto it, while on the other end it becomes so loose that it is doubtful whether it can provide genuine explanation of social phenomena. This is not to say that no satisfactory middle-ground approach is possible. It should nevertheless be highlighted that the dangers of either setting the bar too high or sliding towards the vagueness are very real. And this can be illustrated by briefly reviewing the classical definitions of social capital. Let us note that the latter is quite often introduced as a functional concept. It means that, independent of whatever social capital is precisely taken to be, its function is to secure certain beneficial effects for individuals or groups. ${ }^{5}$ Nevertheless, this claim can be developed into two alternative interpretations, a stronger and a weaker one. Pierre Bourdieu defined social capital as: "[T] he aggregate of the actual or potential resources which are linked to

2 KLIMOWICZ M. Kapitał społeczny. Zagadnienia metodologiczne. In KLIMOWICZ, M., BOKAJŁO, W. (ed.): Kapitał społeczny - interpretacje, impresje, operacjonalizacja. Warszawa : CeDeWu, 2010, p. 44 - 46.

3 PUTNAM R. D. et al. Making Democracy Work. Civic Traditions in Modern Italy. Princeton : Princeton University Press, 1993.

4 PUTNAM R. D. Bowling Alone: the Collapse and Revival of the American Community. New York, London, Toronto, Sydney, Singapore : Simon \& Schuster, 2000.

5 However, not all the beneficial effects of some $\mathrm{x}$ can be taken to be the function of $\mathrm{x}$. Some of those effects may arise unintentionally and accidently. See VORHAUS J. Function and Functional Explanation in Social Capital Theory: A Philosophical Appraisal. In Studies in Philosophy and Education. Vol. 33, No. 2 (2014), p. 188. 
possession of a durable network of more or less institutionalized relationships of mutual acquaintance and recognition". ${ }^{6}$ Bourdieu is not only claiming that having a network of social relationships is functional for securing various resources (material or symbolic) which otherwise would be difficult to obtain for individuals. He is in fact attempting to present a functional explanation of the creation and maintenance of those social networks! In other words, according to him they exist because they provide such benefits: "The profits which accrue from membership in a group are the basis of the solidarity which makes them possible (...) the network of relationships is the product of investment strategies, individual or collective, consciously or unconsciously aimed at establishing or reproducing social relationships that are directly usable in the short or long term, i.e., at transforming contingent relations, such as those of neighborhood, the workplace, or even kinship, into relationships that are at once necessary and elective, implying durable obligations subjectively felt (feelings of gratitude, respect, friendship, etc.) or institutionally guaranteed (rights)".7 This is certainly a very interesting claim, yet also a formidably stringent one. ${ }^{8}$ Functional explanations in general are a contentious subject in the philosophy of science, as critics question their explanatory power. ${ }^{9}$

James S. Coleman approach is more modest as he does not try to provide a functional explanation, but merely a functional definition of social capital. Coleman claims that social capital is " $[\mathrm{N}]$ ot a single entity, but a variety of different entities, with two elements in common: they all consist of some aspect of social structure and they facilitate certain actions of actors - whether persons or corporate actors - within the structure. Like other forms of capital, social capital is productive, making possible the achievement of certain ends that in its absence would not be possible " ${ }^{10}$ To use one of the examples from the field of education that originally inspired Coleman's research, social capital of the children attending religious schools (and presumably therefore also raised in a tightly knit communities) leads to a much lower drop-out rate in comparison with their peers from non-religious public schools. Coleman's definition inspired a great number of similar attempts, although quite often less refined theoretically. However, as Alejandro Portes noted, already the original definition was somewhat blurry and did not clearly distinguish between sources of social capital, its consequences and the resources that it is supposed to allow to obtain. ${ }^{11}$ One of the main problem with functional definitions in general is that the functions of a given $\mathrm{x}$ can be various, changeable and dependent on the socio-cultural context. ${ }^{12}$ Hence the risk of subsuming under one concept a whole range of distinct phenomena. I want to argue that this lead to an increasing lack of clarity about the meaning of social capital, especially as the concept found new applications.

The conceptual stretch that the notion of social capital has undergone is apparent in the case of the other two classics. Both Francis Fukuyama and Robert D. Putnam initiated a turn from hard definitions of social capital which related it to elements of social structure, social roles etc. (i. e.

6 BOURDIEU P. The Forms of Capital. In RICHARDSON J. (ed.): Handbook of Theory and Research for the Sociology of Education. New York : Greenwood Press, 1986, p. 248.

7 BOURDIEU P. The Forms of Capital, op. cit., p. $249-250$.

8 For a more thorough analysis of the demanding conditions that need to be met by a theorist to provide a successful functional explanations see: VORHAUS J. Function..., op. cit., p. 190 - 191.

9 KRAUZ-MOZER B. Teorie polityki. Warszawa : Wydawnictwo Naukowe PWN, 2005, p. 127.

10 COLEMAN J. S. Social Capital in the Creation of Human Capital. In The American Journal of Sociology. Vol. 94 (1988), p. 98.

11 PORTES A. Social Capital: Its Origins and Applications in Modern Sociology. In Annual Review of Sociology. Vol. 24 (1998), p. $5-6$.

12 KWIATKOWSKI M. Aksjonormatywne aspekty kapitału społecznego. In Kapitał społeczny we wspólnotach. Zeszyty Naukowe - Akademia Ekonomiczna w Poznaniu. Vol. 58 (2005), p. 81. 
Bourdieu and Coleman) towards soft definitions which emphasized the shared values and norms, trust and reciprocity. ${ }^{13}$ According to Fukuyama social capital can be defined as: "[T]he ability of people to work together for common purposes in groups and organizations." ${ }^{14}$ This is rather general and vague definition and social capital here begins to approach something akin to a shared culture of a given community. Fukuyama's use of the concept also emphasized the link between the common values and norms on the one hand and generalized trust which in turn reduces transactional costs on the other, a move which quickly became a staple of literature on social capital.

Putnam's starting point in Making Democracy Work. Civic Traditions in Modern Italy was not far removed from Coleman's, as he defined social capital in the following way: "[F]eatures of social organization, such as trust, norms, and networks, that can improve the efficiency of society by facilitating coordinated actions". ${ }^{15}$ Yet, it is worth pointing out that trust, norms and networks are not elements belonging to the same realm. For instance, trust is typically understood as a subjective attitude while the norms which are enforced by a given society are clearly independent of individual's will. Nor do norms and social networks, although certainly related, belong on the same level of social reality. Putnam was quite harshly criticized for looseness of his definition. But that did not detract him from arguably stretching the concept of social capital a bit further in Bowling Alone: the Collapse and the Revival of American Community. This time the concept refers to: "[C] onnections among individuals - social networks and the norms of reciprocity and trustworthiness that arise from them" ${ }^{16}$ If all social relations involving reciprocity and trust are to be considered forms of social capital, the theoretical net has indeed been cast very widely.

Thirdly, the move from hard to soft definitions of social capital which was sketched above opened the way for the conclusion that the latter can be a kind of a collective asset, an attribute of large groups like nations or whole societies. For Bourdieu social capital was a private good, ${ }^{17}$ it was an individual who could benefit in various ways from the possession of well placed acquaintances. Coleman already emphasized that it is a public good, but characteristically he attributed it to relatively small groups: families, local communities, parental associations etc. ${ }^{18}$ Yet, with Putnam and Fukuyama it becomes possible to speak about the stock of social capital in the whole regions or even in the American, Japanese or Polish society. Alejandro Portes rightly pointed out that: "[T]he transition of the concept from an individual asset to a community or national resource was never explicitly theorized, giving rise to the present state of confusion about the meaning of the term. In one sentence, social capital is an asset of children in intact families; in the next, it is an attribute of networks of traders; and in the following, it becomes the explanation of why entire cities are well governed and economically flourishing while others are not. The heuristic value of the concept suffers accordingly as it risks becoming synonymous with each and all things that are positive in social life." ${ }^{19}$ Moreover, the shift from small to large social grouping in application of the concept has an

13 On the distinction between "hard" and „soft” groups of definitions of social capital as well as mixed approaches see: KAŹMIERCZAK T. Kapitał społeczny a rozwój społeczno-ekonomiczny - przegląd podejść. In KAŹMIERCZAK T., RYMSZA M. (ed.): Kapitał społeczny. Ekonomia społeczna. Warszawa : Fundacja Instytutu Spraw Publicznych, 2007, p. $44-45$.

14 FUKUYAMA F. Trust: The Social Virtues and the Creation of Prosperity. New York : Simon \& Schuster, 1995, p. 10.

15 PUTNAM R. D. et al. Making Democracy Work, op. cit., p. 167.

16 PUTNAM R. D. Bowling Alone: the Collapse and Revival of the American Community, op. cit., p. 19.

17 BOURDIEU P. The Forms of Capital, op. cit., p. 249

18 COLEMAN J. S. Social Capital in the Creation of Human Capital, op. cit., p. 116 - 118.

19 PORTES A. The Two Meanings of Social Capital. In Sociological Forum. Vol. 15, No. 1 (2000), p. 3. 
unwelcome consequence of obscuring the ways in which group interests often collide with what is considered to be the good of general public. Smaller collectives are frequently very effective at securing various benefits for themselves at the exclusion of the outsiders. In that sense it can be said that criminal organizations like mafia, lobbyists or some ethnic minority groups are indeed very successful at accumulating and using social capital, although their actions are detrimental to the good of the whole society impartially conceived. Hence the importance of drawing attention not only to the "bright side" of social capital, but also to the negative social capital. ${ }^{20}$ This was also recognized in a way by Putnam who distinguishes between bridging (inclusive) and bonding (exclusive) social capital. The former characterizes social networks which: "are outward looking and encompass people across diverse social cleavages", while the latter tends to "reinforce exclusive identities and homogeneous groups". ${ }^{21}$ This distinction between bridging and bonding social capital will be revisited in the second part of the paper.

Fourthly, it is frequently the case, especially with the broad definitions of social capital, that it becomes very difficult to disentangle the causes or sources of social capitals from its effects and even from its forms. For instance, it is claimed that social capital facilitates collective action, yet at the same time the growth of social capital is supposed to be an outcome of collaborative efforts. ${ }^{22}$ Needless to say, this is an example of circular reasoning. The other option is, unfortunately, that the explanation based on social capital ends up being trivial. If the latter simply means that ordinary citizens trust each other and deeply care about the public good, then indeed it is not hard to see that countries blessed with such citizens would be better governed than others. But that is a commonplace. As Portes noted in his scathing critique of Putnam attempts to account for the differences in the quality of governance and economic prosperity of Italian cities and regions in terms of the differences in their social capital resources: "More insidious, however, is the search for full explanation of all observed differences, because the quest for the prime determinant often ends up by relabeling the original problem be explained. This happens as the elimination of exceptions reduces the logical space between alleged cause and effect so that the final predicative statement is either truism or circular" ${ }^{23}$

Fifthly, there are considerable problems with operationalizing the concept of social capital for the purposes of empirical research. Partially the very choice of word "capital" can be potentially misleading here. Physical capital is tangible and easily measurable, but human capital which comprises the individual skills and competences is much less so. And social capital as a property of relations between the individuals (independent of how precisely we define it) is even more elusive and intangible. Therefore, the resources of social capital can typically be assessed indirectly, by using indicators which are observable. While some progress has been achieved in that regard, for instance in the operationalization of the concept in the research conducted by the World Bank, the problem of identifying indicators which would at the same time be adequate, universal and applicable in different social contexts remains. Furthermore, the aggregation of various components of social capital in order to create its indexes has proven to be controversial, similarly the issue of direction of causality in explaining for instance the relations between trust and cooperation. ${ }^{24}$ In the field of

20 PORTES A. Social Capital: Its Origins and Applications in Modern Sociology, op. cit., p. 16 - 18.

21 PUTNAM R. D. Bowling Alone: the Collapse and Revival of the American Community, op. cit., p. 22 - 23.

22 RYMSZA A. Klasyczne koncepcje kapitału społecznego. In KAŹMIERCZAK, RYMSZA(ed.): Kapitał społeczny. Ekonomia społeczna, op. cit., p. 38.

23 PORTES A. Social Capital: Its Origins and Applications in Modern Sociology, op. cit., p. 20.

24 THEISS M. Operacjonalizacja kapitału społecznego w badaniach empirycznych. In Kapitał społeczny we wspólnotach. Zeszyty Naukowe - Akademia Ekonomiczna w Poznaniu. Vol. 58 (2005), p. 67 - 68. 
studies dedicated to the relations between social capital and economic inequalities among frequently reported problems are: the piecemeal character of conducted research which leads to ambiguous or contradictory conclusions, limited comparability of research results due to the use of different data sets (various countries and measures of social capital, different time frames etc.) and methods. ${ }^{25}$ All those methodological difficulties are by no means fatal to social capital theories, yet they are also worth noting.

Final critical remark concerns the normative aspect of the concept as well as the political agenda underlying its uses in the public discourse. I already mentioned that there is a notable tendency to glance over the potential "dark side" of social capital and to treat it almost as a magical remedy for all ills of contemporary societies. ${ }^{26}$ Naturally, scientists will not have much use of the concept which is so malleable as to fit whatever one finds good and valuable. But indeed that is perhaps precisely where one of the attractions of social capital lies for politicians and public figures. ${ }^{27}$ It is a vague term, but at the same time associated with all the desirable qualities. What is truly remarkable is the political career of the concept over the last few decades. In a thought provoking article Emanuele Ferragina and Alessandro Arrigoni argue that the theory of social capital by merging individualism of rational choice theory with concerns about the communal ties became a crucial instrument of the neoliberal political project. This hypothesis can be even put more sharply - social capital theory became something akin to the ideology which masks the internal inconsistencies of the neoliberal policies. Ferragina and Arrigioni claim that: "[D]espite the significant increase in economic inequality generated by the aforementioned (neoliberal - K. A.) policies of the $1980 \mathrm{~s}$ and $1990 \mathrm{~s}$, political rhetoric based on social capital theory helped to conceal the contradiction between the encouragement of civic engagement and the neoliberal political agenda" ${ }^{28}$ I am not sure whether I would wholly embrace that interpretation, yet it is undeniable that social capital suits the rhetorical purposes of many incompatible political standpoints. It has been used by liberals, conservatives, social democrats, communitarians, contemporary republicans. And this raises suspicion that the concept itself is ready-made for ideological purposes, easily manipulated to justify policies and goals which are at odds with each other.

\section{THE CASE OF POLAND}

In the second part of this essay I want to argue that some of the criticism highlighted above is significant for understanding the role of social capital in the explanation of low level of participation in public life by the Polish people. By participating in public life I do not only mean regularly voting in the local and national elections, involvement in the political parties and other activities which are conventionally described as political participation. Of equal importance is membership in voluntary associations which are often said to form the backbone of the civil society: charities, trade unions, parents' organizations, ecological movements etc. Poland, similarly to other postcommunist coun-

25 WOSIEK M.: Kapitał społeczny w kontekście nierówności ekonomicznych - wybrane aspekty teoretyczne. In Optimumstudia ekonomiczne. Vol. 80, No. 2 (2016), p. 42.

26 KIERSZTYN M. Kapitał społeczny - ideologiczne konteksty pojęcia. In Kapitał społeczny we wspólnotach. Zeszyty Naukowe - Akademia Ekonomiczna w Poznaniu. Vol. 58 (2005), p. 50.

27 PORTES A. The Two Meanings of Social Capital, op. cit., p. 4.

28 FERRAGINA E., ARRIGIONI A. The Rise and Fall of Social Capital: Requiem for a Theory? In Political Studies Review. Vol. 15, No. 3 (2017), p. 361. 
tries, has struggled in both regards. Since the breakthrough of 1989 the level of political participation has remained fairly low, despite occasional periods of greater mobilization and involvement. Similarly, Poles are also much less likely to be actively engaged in the voluntary organizations than the majority of the EU societies. Therefore, the lack of willingness to participate in public life is typically interpreted as clear evidence of the deficiencies of social capital in the Polish society. I want to argue that there are two main factors emphasized by the proponents of this popular interpretation: 1) absence of certain skills necessary for involvement in voluntary organizations and perhaps also in democratic politics 2) low level of trust towards public institutions and other people in general. But how convincing are those explanations?

Let us start with the involvement of the Polish people in voluntary associations. The level of the latter has been consistently low, especially in comparison with some European countries. For instance, in a survey from 2015 the average number of organizations to which respondents older than 16 belonged in Poland was 0,14. For comparison, in Sweden, which topped the European Social Survey 2002 in that regard, the same number was $2,5 .{ }^{29}$ Moreover, most of the Poles who declare active involvement in voluntary associations typically belong to religious organizations, sport clubs, hobby groups. Few are members of trade unions, professional associations, organizations created for the promotion of knowledge or protection of the environment and of political parties. ${ }^{30}$ Furthermore, many of the officially registered non-governmental organizations are in fact inactive or are acting only sporadically. This brings us directly to the issue of social capital. There is a popular argument which appears in many variations, so for illustration I will use one example. Efficient and prosperous functioning, the argument goes, of a modern "developed, democratic and market society" 31 requires the possession of a certain set of skills by its members. Polish sociologist Piotr Sztompka describes them jointly as civilizational competence which is necessary for successful, authentic modernization. At least some ingredients of civilizational competence can be treated as forms of social capital. Sztompka mentions for instance: political activism, readiness to participate, concern with public issues. ${ }^{32}$ Unsurprisingly the period of "real socialism" in Poland is identified as the one which not only thwarted the development of these valuable skills, but bred its own, peculiar kind of civilizational incompetence. ${ }^{33}$ Firstly, this argument becomes progressively weaker in explaining the meagerness of voluntary associations as more time has passed since the collapse of socialism in Poland, although admittedly the cultural changes belong to the long term processes. There is however another difficulty I wanted to highlight. It seems that the skills listed above can typically be acquired only through successful collective agency, through acting in concert with others. So it turns out that Polish people are not good at cooperating, because they do not have the relevant competences. But do not have the relevant competences since they do not cooperate with one another. ${ }^{34}$ The reasoning is obviously

29 CZAPIŃSKI J., PANEK T. (ed.): Diagnoza społeczna 2015. Warunki i jakość życia Polaków. Warszawa : Rada Monitoringu Społecznego, 2015, p. 354

CZAPIŃSKI J., PANEK T. (ed.): Diagnoza społeczna 2015, op. cit., p. 340 - 341.

31 SZTOMPKA P. Civilizational Incompetence: The Trap of Post-Communist Societies. In Zeitschrift für Soziologie. Vol. 22, Is. 2 (1993), p. 88.

32 Ibid., p. 89.

33 Ibid.

34 This is a reiteration of the statement taken directly from the commentary on the results of social survey quoted above. The original passage goes as follows: "Polish people are not capable of organizing and acting effectively together unless it is about the strike or protest (...) They are not capable since they did not learn to do so from their meagre experience in that regard. They are not capable because they do not act together and they do not act together because they are not capable - this is the vicious circle of social engagement.." CZAPIŃSKI J., PANEK T. (ed.): Diagnoza społeczna 2015, op. cit., p. 348. 
circular. Furthermore, there might be a good deal of truth about the mutually reinforcing lack of relevant skills and the lack of activity in organizations of the civil society. But we also do not learn from it how to break this vicious circle. ${ }^{35}$

Proceeding now to the issue of trust. There is indeed ample evidence that Polish people do not trust public institutions, especially the more directly involved these institutions are in political struggles and party interests. For instance, in a recent survey a majority of respondents declared that they trust local authorities, the President of Poland (the office symbolizes the country's splendor) and even public administration officials. At the same time most of them did not trust the government, both chambers of the Polish Parliament, courts, television and newspapers. ${ }^{36}$ In the same survey $63 \%$ of respondents were distrustful towards political parties in general (not towards any particular party). ${ }^{37}$ It is important to stress that although the results of the discussed survey might have been influenced by the events at the time when it was conducted, clear patterns of mistrust towards the political institutions have been confirmed time and again by other research as well.

Moreover, the problem is not limited to low level of trust towards public institutions. The results of research suggest that the same can be said about generalized (social) trust. In 2018 the number of Poles who agreed with a statement "Generally speaking, most people can be trusted" was $22 \%$. Correspondingly, $76 \%$ of respondents declared that "It is better to be careful in relations with others". ${ }^{38}$ For comparison, the number of those who agreed that "most people can be trusted" in all 3 countries (Denmark, Finland, Norway) which topped the European Social Survey 2014 in that regard was well over $60 \% .{ }^{39}$ As mentioned before, the low level of generalized social trust is characteristic for postcommunist countries (with a notable exception of Estonia), although the results of European Social Survey 2014 suggest that both Czechs and Hungarians are a bit more trustful than Poles. ${ }^{40}$ It is also worth mentioning that in 2018 the percentage of the Polish people who distrust strangers was the highest in the recorded history of the CBOS survey. ${ }^{41}$

It is a staple of sociological literature that the scarcity of trust in the Polish society is rooted in the period of communism and the habits of thought and action that it cultivated. Already in the 70s sociologist Stefan Nowak claimed that in Poland there was a sociological vacuum created by the lack of intermediary institutions between the level of primary groups and the level of national community. ${ }^{42}$ As a result, individuals were socialized to act only for the benefit of family and close friends. Those outside this small circle were to be treated with suspicion as potential rivals in a competition for various scarce resources. It is not my goal here to contest that established interpretation, since I agree that it contains a lot of truth. Nevertheless, I wanted to argue that it overshadows

35 Sztompka's article is worth revisiting 25 years after its publication for various reasons, one of them being the authors suggestions how the civilizational incompetence could be (and arguably also will be) overcome. The desirable influence of processes such as globalization, technological progress and democratization in that regard is indeed hard to deny, but in hindsight also seems too optimistic. SZTOMPKA P. Civilizational Incompetence: The Trap of Post-Communist Societies, op. cit., p. $93-94$.

36 CBOS. Komunikat $\mathrm{z}$ badań Nr 35/2018, O nieufności i zaufaniu, p. 7 - 8 .

37 Ibid., p. 7.

38 Ibid., p. $1-2$.

39 CZAPIŃSKI J., PANEK T. (ed.): Diagnoza społeczna 2015, op. cit., p. 352.

40 Ibid.

41 CBOS. Komunikat z badań Nr 35/2018, op. cit., p. 3.

42 DZWOŃCZYK J. Kapitał społeczny a rozwój społeczeństwa obywatelskiego w Polsce. In KRAUZ-MOZER B., BOROWIEC P. (ed.): Samotność idei? Społeczeństwo obywatelskie we współczesnym świecie. Kraków : Oficyna Wydawnicza AFM, 2007, p. 62. 
other causes that could have contributed to the deficiencies of trust in the Polish society. Among the factors which are antithetical to the flourishing of trust in society one can list: anomie (normative disorder), instability of the social order, lack of transparency in the social organization (in the operations of institutions, associations, groups), strangeness and unfamiliarity of the social environment, lack of accountability and arbitrariness of individuals and institutions. ${ }^{43}$ It is reasonable to assume that the social reality of Poland in the 90s, when the transformation of the political and economic system was most dramatic, could well have been characterized by at least some of these phenomena. Moreover, as Ferragina and Arrigioni argue: "[S]ocial capital does not seem to flourish when high inequalities persist in society". ${ }^{44}$ In Poland, as a result of the economic reforms of the early $90 \mathrm{~s}$ the inequalities within society grew very quickly and exponentially. It is beyond the scope of this essay and beyond the competences of its author to establish how persistent those inequalities have proved to be. Yet, almost 30 years after the political and economic transformation was initiated it seems uncontroversial that while most social groups are materially much better off, certainly not all have benefited equally. Moreover, it is misleading to suggest that expectations of a substantial part of the Polish society that the state to promote a more substantial economic equality and welfare of citizens can be simply reduced to the pathological legacy of real socialism in Poland. ${ }^{45}$ The caricature of homo sovieticus with a clientelist mentality, lack of resourcefulness and downward leveling tendencies becomes all too easily an ideological construct used in order to discredit perfectly legitimate expectations. There is nothing inherently contradictory in the notion that democracy should mean not only free elections, but also greater equality.

Moreover, the lamentable tone of many works on trust and social capital in Poland is perhaps somewhat unnecessary. Since it is possible to interpret the distrustfulness of the Polish society not as an evidence of the lack of social capital, but as a sign of its ample resources. It all turns on what kind of social capital is under consideration. Recall the Putnam's distinction between bridging (inclusive) and bonding (exclusive) social capital. The former encompasses relations between people from very different social backgrounds, while the latter is characteristic for relatively small, tight and homogenous groups. Sociological research confirms that Poles are most trustful towards family members and close friends. So it would seem perfectly reasonable to conclude that it is the bridging social capital that is scarce in the Polish society, while the bonding social capital is not at all lacking. One might obviously claim that the whole point of the argument right from the start was to stress that it is precisely the right, desirable kind of social capital that is missing in Poland. But is it really that obvious? Is bridging social capital indeed so indispensable? And if it is, are we really entitled to conclude, based on the quoted research on trust, that it is a scarce resource among Polish people? Firstly, the low level of trust might indeed adversely affect the quality of life and participation in public affairs, yet so far it does not seem to have hampered the economic development of the country. As sociologist Andrzej Rychard noted already some time ago, the relatively good performance of Polish economy over the years might falsify the hypothesis put forward by Fukuyama and Putnam that social capital in the form of trust is necessary for economic development and modernization. It might also be the case that sooner or later the lack of bridging social capital will "catch up" with

43 SZTOMPKA P. Zaufanie: fundament społeczeństwa. Kraków : Wydawnictwo Znak, 2007, p. 276 - 281.

44 FERRAGINA E., ARRIGIONI A. The Rise and Fall of Social Capital: Requiem for a Theory?, op. cit., p. 357 - 358 . On the complex relations between social capital and economic inequalities described in the scientific literature see also: WOSIEK M.: Kapitał społeczny w kontekście nierówności ekonomicznych - wybrane aspekty teoretyczne, op. cit., p. 39 - 54.

45 For an example of this see: DZWOŃCZYK J. Kapitał społeczny a rozwój społeczeństwa obywatelskiego w Polsce, op. cit., p. $72,75-76$. 
Polish economy and limit the possibilities of further development. None of these possibilities is to be easily discarded. Yet, there is also a third option, that there are some hidden resources of social capital in the Polish society, or substitutes of it, which are not easily detectable in standard social research. ${ }^{46}$ Rychard claims that those hidden resources can perhaps be located not only in pathological relations (like corruption), but also in informal, but not pathological, networks and procedures which contribute to the integration of the society. ${ }^{47}$

\section{CONCLUSION}

Over the course of this paper I tried to show that the concept of social capital is burdened with some considerable limitations. I do not claim that the difficulties I mentioned must prove fatal for the concept itself and for the theories employing it. Nor do I want to diminish the value of majority of research conducted by scholars worldwide which is related to social capital. My goal was simply to caution against the dangers underlying following the fashionable trend. In my view key among these are: the vagueness of the concept which invites circularity in reasoning and its propensity to serve the expression of normative and political convictions of its users. I used the example of how social capital frequently features in explanation of the unwillingness of the Poles to participate in the public life in order to highlight these points. While Polish people are indeed not very active in public matters, this does not in itself mean that social capital of the society is low (unless one makes it so by definition), nor is it obvious that its deficiencies are to be located in the remains of the socialist mentality. Insofar as other possible explanations are obscured by the ones including social capital, a particular caution is advised.

\section{Bibliography:}

BOURDIEU P. The Forms of Capital. In RICHARDSON J. G. (ed.): Handbook of Theory and Research for the Sociology of Education. New York: Greenwood Press, 1986, p. $241-258$.

CBOS Komunikat z badań Nr 35/2018, O nieufności i zaufaniu, p. 1 - 14.

COLEMAN J. S. Social Capital in the Creation of Human Capital. In The American Journal of Sociology. Vol. 94 (1988), p. 95 - 120.

CZAPIŃSKI J., PANEK T. (ed.): Diagnoza społeczna 2015. Warunki i jakość życia Polaków. Warszawa : Rada Monitoringu Społecznego, 2015, p. 1 - 545.

DZWOŃCZYK J. Kapitał społeczny a rozwój społeczeństwa obywatelskiego w Polsce. In KRAUZ-MOZER B., BOROWIEC P. (ed.): Samotność idei? Społeczeństwo obywatelskie we współczesnym świecie. Kraków : Oficyna Wydawnicza AFM, 2007, p. 57 - 78.

FERRAGINA E., ARRIGIONI A. The Rise and Fall of Social Capital: Requiem for a Theory? In Political Studies Review. Vol. 15, No. 3, 2017, p. 355 - 367.

FUKUYAMA F. Trust: the Social Virtues and the Creation of Prosperity. New York : Simon \& Schuster, 1995, p. 1 457.

46 RYCHARD A. Kapitał społeczny a instytucje. Wstępne rozważania. In DOMAŃSKI H., OSTROWSKA A., SZTABIŃSKI P. B. (ed.): W środku Europy? Wyniki Europejskiego Sondażu Społecznego. Warszawa : Wydawnictwo IFiS PAN, 2006, p. $212-213$

47 Ibid., p. 214. 
KAŹMIERCZAK T. Kapitał społeczny a rozwój społeczno-ekonomiczny - przegląd podejść. In KAŹMIERCZAK T., RYMSZA M. (ed.): Kapitał społeczny. Ekonomia społeczna. Warszawa: Fundacja Instytutu Spraw Publicznych, 2007, p. $41-64$.

KIERSZTYN M. Kapitał społeczny - ideologiczne konteksty pojęcia. In Kapitał społeczny we wspólnotach. Zeszyty Naukowe - Akademia Ekonomiczna w Poznaniu. Vol. 58 (2005), p. 42 - 52.

KLIMOWICZ M.: Kapitał społeczny. Zagadnienia metodologiczne. In: KLIMOWICZ M., BOKAJŁO W. (ed.): Kapitał społeczny - interpretacje, impresje, operacjonalizacja. Warszawa: CeDeWu, 2010, p. 43 - 52.

KRAUZ-MOZER B. Teorie polityki. Warszawa : Wydawnictwo Naukowe PWN, 2005.

KWIATKOWSKI M. Aksjonormatywne aspekty kapitału społecznego. In Kapitał społeczny we wspólnotach. Zeszyty Naukowe - Akademia Ekonomiczna w Poznaniu. Vol. 58 (2005), p. 73 - 84.

PORTES A. Social Capital: Its Origins and Applications in Modern Sociology. In Annual Review of Sociology. Vol. 24 (1998), p. 1 - 24 .

PORTES A. The Two Meanings of Social Capital. In Sociological Forum. Vol. 15, No. 1 (2000), p. 1 - 12.

PUTNAM R. D. et al. Making Democracy Work. Civic Traditions in Modern Italy. Princeton: Princeton University Press, 1993, p. $1-275$.

PUTNAM R. D. Bowling Alone: the Collapse and Revival of the American Community. New York, London, Toronto, Sydney, Singapore : Simon \& Schuster, 2000, p. 1 - 544.

RYCHARD A. Kapitał społeczny a instytucje. Wstępne rozważania. In: DOMAŃSKI H., OSTROWSKA A., SZTABIŃSKI P. B. (ed.): W środku Europy? Wyniki Europejskiego Sondażu Społecznego. Warszawa : Wydawnictwo IFiS PAN, 2006, p. $201-219$.

RYMSZA A. Klasyczne koncepcje kapitału społecznego. In KAŹMIERCZAK T., RYMSZA M. (ed.): Kapitał społeczny. Ekonomia społeczna. Warszawa: Fundacja Instytutu Spraw Publicznych, 2007, p. 23 - 39.

SZTOMPKA P. Civilizational Incompetence: The Trap of Post-Communist Societies. In Zeitschrift für Soziologie. Vol. 22, Is. 2 (1993), p. 85 - 95.

SZTOMPKA P. Zaufanie: fundament społeczeństwa. Kraków : Wydawnictwo Znak, 2007, p. 1 - 420.

THEISS M. Operacjonalizacja kapitału społecznego w badaniach empirycznych. In Kapitał społeczny we wspónotach. Zeszyty Naukowe - Akademia Ekonomiczna w Poznaniu. Vol. 58 (2005), p. 59 - 69.

VORHAUS J. Function and Functional Explanation in Social Capital Theory: A Philosophical Appraisal. In Studies in Philosophy and Education. Vol. 33 (2014), p. 185 - 199.

WOSIEK M. Kapitał społeczny w kontekście nierówności ekonomicznych - wybrane aspekty teoretyczne. In Optimum- studia ekonomiczne. Vol. 80, No. 2 (2016), p. 39 - 54.

\section{Contact information:}

Kamil Aksiuto, $\mathrm{PhD}$

kamaks@poczta.umcs.lublin.pl,kamilaksiuto@wp.pl

Maria Curie-Skłodowska University in Lublin

Faculty of Political Science

Jantarowa 14/19

postal code: $20-582$

Lublin

Poland 